\title{
EUROPEAN DIMENSION OF PROFESSIONAL TRAINING OF PRIMARY SCHOOL TEACHERS IN HUNGARY: EXPERIENCE FOR UKRAINE
}

\author{
Kateryna Hodlevska \\ Institute for Education Studies \& Adult Education \\ of the National Academy of Pedagogical Sciences of Ukraine, Kyiv, Ukraine \\ hodlevskakat2611@mail.ru
}

\begin{abstract}
The article analyzes the features of the organizational structure and content of vocational teacher training in Hungary at present time. It also reveals the positive factors that contribute to the improvement of Hungarian higher education system under the Bologna agreement. It has been found that according to the type of qualification, the Hungarian teacher education system prepares preschool teachers (övodapedagögus), primary school teachers (tanitö), junior middle school teachers (tanarand), senior middle school teachers (közepiskolai tanar), special teacher-trainers (gyögypedagögm). The curricula of teacher training in "Primary education" have been studied. The comparative analysis of training primary school teachers in Hungary and Ukraine was performed and possibilities of implementing progressive ideas of Hungarian experience in reforming teacher education in Ukraine have been considered. According to the Hungarian model of teacher education, revised in light of the Bologna process, the practical primary school teacher training takes place during the 2nd cycle of studies. That means that the Hungarian model, unlike the Ukrainian one, presupposes the teaching practice only for those students who choose pedagogical area at admission to a Master's programme. A positive feature of content formation of Hungarian teacher training is the priority of practical training, which implies acquisition of practical-oriented knowledge, providing professional and personal development of future teachers. Specific ways to further improvement of the national system of teachers training based on creative use of progressive ideas of Hungarian experience are outlined.
\end{abstract}

Keywords: professional training; primary school teacher; European dimension; structure and content of professional training; teaching practice; Hungary.

Introduction. Profound changes in the socio-economic and spiritual development of Ukrainian society, the desire to integrate into the global educational space, association with the Bologna Process and the Lisbon Convention, creation of European system of higher education and research, induce the social procurement of the state for preparation of a new generation of teachers. That is why the beginning of XXI century in Ukraine is marked with the search of innovative approaches to teacher training. The process of the higher education system reformation has been systematically implemented in European countries for a long period of time. However, the main objectives of the Bologna Declaration for the achievement of common content and quality of European education are implemented differently in different countries. In this context, the importance of the study of specific organization and functioning of teacher education systems in major European countries including Hungary is increasing.

The Hungarian experience in teacher training has been studied quite insufficiently by Ukrainian researchers (W. Gomonay, E. Borkach M. Levrints, I. Keresten, J. Miss, V. Saharda et al.). The issue of primary school teacher training in Hungary has never been investigated.

Hungary, the closest western partner of Ukraine, in recent years, has strengthened the prestige of its education among European countries with the introduction of qualitative changes in all spheres of educational activities.

We believe that creative research, objective analysis, evaluation and comparison of the relevant Hungarian and national experiences will contribute to the enrichment of the Ukrainian pedagogical science with new ideas and achievements which will lead to a comprehensive modernization and transformation of Ukrainian higher pedagogical education according to Bologna system requirements, ensure the successful integration of national education to the European educational space.

The purpose of the study is to identify the specific features of professional training of primary school teachers in Hungary in the context of the creation of a common European educational space and to substantiate the possibilities of using the progressive ideas of the Hungarian experience in the reformation of pedagogical education in Ukraine.

Specific features of training primary school teachers in Hungary. To solve the research objectives we have performed the analysis of legal and regulatory documents, available teaching 
regulations and electronic resources of the Ministry of Education and higher educational establishments in Hungary, professional literature on the theory and methodology of training primary school teachers.

The research of teacher training in Hungary requires the definition of the term "teacher training". The analysis of different interpretations of this term showed its multifunctionality and multivariance. Most Hungarian researchers understand it as the complex of all higher educational programmes, after completion of which the graduates are eligible to work as teachers (Sistemy obrazovanija, 2015).

We found out that according to the type of qualification the Hungarian teacher education system prepares preschool teachers (övodapedagögus), primary school teachers (tanitö), junior middle school teachers (tanarand), senior middle school teachers (közepiskolai tanar), special teachertrainers (gyögypedagögm) (Borkach \& Poor, 2010, p. 404).

According to 381/2004. (XII.28.) Decree concerning the changes in the vocational teacher training system in Hungary, it was decided to move from the dual to the cyclic system of teacher training, according to which teacher education covers the second cycle (Master's programme). Thus, the teacher's diploma for all educational specialities in Hungary can be obtained only at the Master's level. During the first cycle of education (Bachelor's programme) students learn professional disciplines, regardless of their further specialization in professional and educational courses. In 2005, Hungary adopted a number of legal documents on secondary school teacher training, which specified and updated content and objectives of teacher education requirements and criteria of teachers' professional skills. In particular, the professional Master's degree involves obtaining of at least 40 credits in psychological and pedagogical disciplines and 30 credits in school teaching practice for 6 months' period. The pedagogical component of the curriculum consists of 80 credits, including 10 credits which students can get during the first cycle of training for learning profession courses. Additional points are given for studying courses in professional discipline teaching methods within the limit of 10 credits (Levrints, 2010a, p. 69).

One of the innovations of teachers training in Hungary is the organization of the majority of learning activities in small groups of students, explicit practical orientation of the educational process. The leading role in the Hungarian pedagogical education is attributed to specialists in professional disciplines teaching methods who must establish and maintain close contacts between university and school, regularly consult students of pedagogical specialities. For this purpose, the intensive work is conducted on the development and implementation of appropriate courses of advanced teacher training in the country. Of particular importance are training courses for managers of teaching practice - mentors (or supervisors as they are usually called in many Western countries). These courses are held at Eötvös University of Budapest (Levrints, 2009, p. 65).

The curriculums of pedagogical professional training include the study of such disciplines as: axiology, anthropology, social psychology, social pedagogy, psychological trainings, a number of optional disciplines including multicultural education, multimedia presentation, ethics and aesthetics, information technology, distance learning, environmental education, sociology, humanistic ecology and others.

The analysis of teacher training curricula in "Primary education" shows that, along with two obligatory disciplines which they will be able to teach in the $5-6^{\text {th }}$ grades, there are new disciplines such as ethnology, environmental education, ethics, puppet theater, housekeeping and others. Development of professional teacher training is accompanied with the increase in choice of specializations offered to future teachers (valeology, fundamentals of economics, recreation, information technology, fine arts, dance, etc.) (Levrints, 2010b, p. 71).

Some of the lectures which are delivered by academics of Department of Pedagogy at Nyiregyhaza Pedagogical Institute include "Teaching and learning", "Education system in Hungary", "Education system in Europe", "Education Policy in Europe", "Education and andragogy", "Differentiated teaching methods", "Evaluation in teacher's work" and others (Institute of primary school teacher training, 2015).

A positive feature of content formation of Hungarian teacher training is the priority of practical training, which implies acquisition of practical-oriented knowledge, providing professional 
and personal development of future teachers. For that purpose, the transition has been made to a sixmonth term of teaching practice in school. The mobility and flexibility of the teacher training system are combined with its planned character, forecasting of future needs of the labor market and the current requirements to the teacher's personality, reflected in the qualification characteristics. Implementation of new educational projects is possible after taking part in a tender procedure (Mis, 2010, p. 89).

The results of the study suggest that an important task of the Hungarian teacher education in the context of the creation of the European higher education space is to develop mechanisms that comprehensively optimize the academic mobility. According to J. Temeszów such mechanisms are Qualifications Framework and ECTS.

Legislative support of modernization of training primary school teachers in Hungary. In 2005, Hungary began a national consultation process to develop the national qualifications framework. Following the conclusions of experts and scientists, the Ministry of Education and Culture (now the Ministry of Human Resources) and the Ministry of Social Affairs and Employment (now the Ministry of National Economy) prepared a joint recommendation for the government to accede to the European Qualifications Framework and to create the National Qualifications Framework ("Orszagos Kepesitesi Keretrendszer", OKKJU). On the 6th of June 2008, the Hungarian Government Decree 2069/2008 (VI 6.) on "Establishment of the State Qualifications Framework" was adopted (Az Európai Képesítési Keretrendszerhez való csatlakozásról és az Országos Képesítési Keretrendszer létrehozásáról1, 2008).

According to the resolution, in October 2008, an interagency commission was created, which, under the supervision of the Ministry of Education and Culture, coordinated the activities related to the development of the State Qualifications Framework.

The following results are expected of the implementation and operation of the Qualification Framework:

1) improvement in the transparency of education and training system that will facilitate the orientation of all members of the learning process and labour market to the content of qualifications, their practical applicability; improve the effectiveness of education and training, recognition of qualifications;

2) increase in mobility between education and training systems as well as formal and informal learning trajectories (increased attractiveness of learning within the whole society, improvement of the social component of education, access to various forms of training, increase in opportunities for academic mobility);

3) creation of professional and legal conditions for accession to the European Qualifications Framework, so that Hungary over time will become an active participant in the European space of higher education; in Europe the confidence will increase in the qualifications obtained in Hungary, the international attractiveness of the Hungarian higher education system will grow; the competitiveness of Hungarian higher educational institutions in the European labor market will strengthen.

ECTS has existed in Hungary since the mid 1990-s. After joining the Bologna process it has undergone minor changes and has been operating till present.

Hungarian Law on Higher Education of 2005 (Paragraph 2.1) is aimed at developing a system which guarantees a high quality of higher education, allows students to gain a high level of knowledge applicable in the national and foreign labor market.

The study of the quality assurance of Hungarian higher education system in contexts of the Bologna process was conducted by the following Hungarian scientists: J. Balint, D. Bazha, A. Dereni, T. Kozma, I. Poloni, J. Topar and others.

In Hungary, the objectives of higher education quality assurance were divided among the Ministry of Education and Culture (now the Ministry of Human Resources), the Hungarian Accreditation Committee of Higher Education (HAC) and educational institutions.

To ensure a high quality of higher education it is necessary to have an independent organization for its control, whose role in Hungary is performed by HAC. In its work the organization uses the European standards and principles of quality assurance. 
According to the Law of Hungary on Higher Education, higher educational institutions of the country were required to establish an internal quality assurance system and provide the conditions for its functioning in all departments. Each institution must design a quality improvement program, within which task management, planning, monitoring, measuring and assessment of quality, protection of consumer rights are defined. The program determines the mechanism of evaluation of teachers' activity by students. The institution's authority must annually assess the quality and publish the results on its website in the manner adopted by the institution. Representatives of the institutions are involved in the examination of licensing and accreditation materials relating to specific areas and specialties, doctoral programs, educational grants, self-analysis, expert committees, development and implementation of solutions.

In Hungary, according to Government Decree 221 / 2006.11.15, competition for the prize of quality in higher education was established, which is given to higher education institutions and their departments that made the biggest progress in the development of their own education quality assurance systems. Also, all Hungarian higher educational institutions have the opportunity to invite foreign organizations for quality evaluation, accreditation or consultancy activities.

Comparative analysis of training primary school teachers in Hungary and Ukraine. Our research allowed us to identify the common and distinctive features of professional teacher training in Hungary and Ukraine.

Thus, based on the analysis of legal documents in Ukraine and Hungary, there are some common actions of governments on the implementation of the Bologna education system:

- in Hungary, the Government Decree 77/2002 (IV.13) "On ECTS", and in Ukraine, "The list of areas of Education", approved the directions of teacher training according to new requirements in the paradigm of European education systems;

- Hungary introduced a three-tier higher education system and a two-tier teacher training system, and Ukraine is planning a transition to a three-tier system;

- since 2006/07 school year in Hungary and Ukraine, the educational process in higher education has been taking place according to the recommendations of the European Credit Transfer System (ECTS), though in Hungary ECTS was introduced as early as in 1998.

To improve the training of primary school teachers, Hungary adopted common requirements to the level of teacher professional training in accordance with the requirements of the European Higher Education Area (EHEA). In Ukraine, unfortunately, this was not done.

In Hungary, training of primary school teachers takes place in teacher training colleges, pedagogical institutes and universities; a system of common requirements of industry-specific standards of higher pedagogical education has been introduced; organization of educational activities of higher education institutions is subordinated to the Ministry of Education, Youth and Sports. Whereas in Ukraine, training of primary school teachers is carried out by a network of higher education establishments such as classical universities, pedagogical institutions, Humanities Universities, institutes and teacher training colleges, which are subordinated to several ministries and departments.

Ukraine has just introduced the preparation of specialists to teaching two subjects, while Hungary has big experience in double specialty teacher training, when, along with their major specialty, an additional one is studied, which can be advanced in a Master's programme. Thus, a student can earn two pedagogical diplomas.

One of the tasks of teacher education in Ukraine is to improve the selection of young people for the teaching profession (Ogiienko, 2014, p. 148). However, in our country, there is practically no diagnostics of psychological and individual characteristics of applicants, motivation of their choice of the teaching profession. At the same time, as the results of numerous studies indicate, a significant percentage of applicants are characterized by a low level of motivation to the teaching profession and do not intend to work in the pedagogical sphere.

In Hungary, the problem of diagnostics of professional proficiency and professional choice of future primary school teachers is solved by means of the entrance exam to the Master's degree programme, whose main objective is to test the motivation of future teachers and identify values, guiding the students' choice of this profession. 
Since in Hungary Bachelor's programmes, regardless of further specialization, provide a common curriculum (except for courses in teaching methodology, psychology and pedagogy), professional selection at the end of bachelor's study is quite well-timed considering the fact that the main professional and pedagogical, methodical and practical training of primary school teachers takes place in the Master's programme. Despite the fact that the current practice of teacher selection in Hungary is not perfect, it still minimizes the penetration of random people in the field of pedagogical education. Professional selection for the teaching profession in Hungary has a dual purpose: staffing of schools with motivated teachers; increase in quality of teacher training and education level in general.

The development of psychological and pedagogical culture of future teachers of primary schools in our country is based on the study of traditional subjects like didactics, theory of education, history of pedagogy, general psychology, pedagogical and developmental psychology, comparative pedagogy, fundamentals of pedagogical skills and other disciplines which are studied in Bachelor's programmes and are almost absent in Master's programmes, except of some optional disciplines.

In Hungary, unlike in Ukraine, purely practical courses of pedagogy and psychology within the scope of 10 credits are studied at the level of undergraduate study. Their main task is to promote the commitment of students to the teaching profession and to foster the professional motivation, which is reflected in the name of the curricular block - psychological and pedagogical careerguidance block. This block of subjects is studied by students at their own choice, with the intention to acquire further teacher education in the Master's programme.

For example, students of the Master's degree programme of the University in the city of Peych study such subjects as the history of pedagogy, pedagogical skills, sociology of education, educational activities, training and learning theory, personality development, planning and evaluation of the educational process, psychology of personality, professional self-actualization, school pedagogical culture (optional), information technology in pedagogy, psychological problems of training dichotomy (optional), educational psychology, school education system, development of school, etc.

As we can see, the above-mentioned courses have a more practical bias than the psychological and pedagogical disciplines taught in our country. Thus, in Hungary, the theoretical and practical courses in pedagogy and psychology in Master's degree programmes are studied by more conscious and motivated students who have a purpose to obtain a teacher's diploma.

Methodological training plays a special role in the systems of teacher education in Ukraine and Hungary. In our country, the development of methodological competence of teachers is provided by courses in methodology of teaching, methodology of extracurricular work. In our opinion, methodological orientation of teaching fundamental disciplines is a valuable achievement of training primary school teachers in Ukraine. However, because of the absence of control and regulatory mechanisms and educational materials on the above-mentioned problem, the principle of professional orientation of teaching professional disciplines as a specialty in most cases remains a pure formality.

Formation of methodological competence of the primary school teachers in Ukraine is carried out during the whole period of study of psychological and pedagogical cycle of disciplines, teaching practice and scientific research into teaching methods in high school (Ogiienko, 2013, p. 183).

In Hungary, methodological preparation of primary school teachers is performed during two cycles of study with different proportion of courses in teaching methodology and teaching practice. In the course of study of the basic cycle, students of philological departments who wish to continue education in a Master's degree program in the teaching sphere, study theoretical and practical courses in teaching methodology and optional psychological and pedagogical disciplines, devoted to specific features of educational activities.

After passing the entrance exam to methodological and psycho-pedagogical blocks of a Master's degree program, students who seek to obtain a teacher's diploma, move to an advanced study of these subjects. Methodological training of primary school teachers is completed with writing a master's thesis in teaching methodology and the composition of a portfolio. 
Comparative analysis of the experience of vocational training of primary school teachers in universities of Ukraine and Hungary indicates that Hungary is more active in the development of skills in scientific research during both cycles. Thus, during the 1st and 2 nd cycles, the students study a range of courses aimed at the formation of skills in scientific research: "Fundamentals of scientific research", "Development of writing skills in English scientific style", "Pedagogical research", etc. The development of culture of scientific work is promoted by creative tasks which are widely used in seminars, project works, term papers, theses, etc.

The systems of teacher education in Ukraine and Hungary have a rich heritage of practical teacher training. In our country, the practical training of primary school teachers involves a continuous pedagogical practice, starting from the 3 rd semester. Traditionally, during the $3-6^{\text {th }}$ semesters, students observe classes of experienced teachers at school, with subsequent analysis conducted under the supervision of their practice supervisors. During the $7-9^{\text {th }}$ semesters, students have individual practice which includes the teaching activity (making lesson plans, teaching, analysis of other teachers' classes, making visual aids, etc.), extracurricular work (observation and analysis of extracurricular activities, planning and carrying out certain types of extracurricular activities, etc.), scientific research (survey of students, conducting researches necessary for writing term papers / theses on teaching methods etc.), upbringing of young children (planning and carrying out extracurricular upbringing activities, etc.) (Nikolaieva \& Badaiants, 2001, p. 186).

During their teaching practice, students perform various functions of a teacher and participate in socially useful work of school. At the initial stage of the practice, they meet the schoolchildren, get acquainted with the school documentation, curriculums, define the themes and forms of upbringing activities, attend classes and extra-curricular events of teachers and student interns. At the main stage of the practice, students give classes following the lesson plans, agreed with their practice supervisors, prepare teaching aids, carry out extracurricular and upbringing activities, participate in methodological workshops, make presentations, conduct scientific research, give psychological and pedagogical characteristics of students and the class as a whole, etc.

According to the Hungarian model of teacher education, revised in light of the Bologna process, the practical primary school teacher training takes place during the 2 nd cycle of studies. That means that the Hungarian model, unlike the Ukrainian one, presupposes the teaching practice only for those students who choose pedagogical area at admission to the Master's programme. In Ukraine, all students without exception have teaching practice. In Hungary, due to the current system of vocational selection, practical teacher training really improves the quality of vocational education and promotes motivation to educational activities.

The essential difference between the Hungarian and Ukrainian systems of teacher education is the need for passing a complex exam in Hungarian universities in disciplines of the psychopedagogical cycle and teaching methodology before the beginning of the teaching practice. Students are also trained at special theoretical and practical workshops before and during the practice. It is very important, in our opinion, that students are attached only to teachers who have the qualification of a mentor - a school teaching practice supervisor in Hungary. In Ukraine, there is no wide-spread practice of training teachers to work with interns, so not all of them are fully prepared to perform the functions of mentors.

In the process of teacher training in Hungary, there is an important problem of optimal combination of theoretical and practical components of the organization of educational process at university. At higher educational institutions of Hungary, according to the Resolution of the Government 15/2006. (IV.3., Appendix 4), practical teacher training, including workshops in fundamental disciplines and school teaching practice, covers $65-70 \%$ of the total number of credits in the Master's program.

In Hungary, the improvement of the quality of teacher training is promoted by writing a master's thesis in teaching methodology, in which graduates demonstrate their knowledge and understanding of the phenomena and processes related to the professional work of a teacher, critical approach to the study of scientific and professional literature, acquire and apply practical experience. 
An important achievement of the teacher education system of Hungary is the composition of students' portfolio as part of the master's work in teaching methodology, which includes a variety of authentic materials collected during the teaching practice and workshops in disciplines of professional cycle aimed at the development of professional pedagogical competences of future elementary school teachers.

While in Hungary the teacher training at the Master's level suggests enhanced versatile development of professional pedagogical and methodological competences of the teacher, in Ukraine, the main stage of teacher training is completed at the Bachelor's level, when students study the courses in teaching methodology and the cycle of psychological and pedagogical disciplines. In the Master's program, students in our country have individual teaching practice and in rare cases take optional courses in teaching methodology.

As evidenced by the analysis of experience of professional teacher training in our country, there is an urgent need to review the content and technology of teacher training and retraining, due to certain imperfections in this area:

- overestimation of the importance of theoretical knowledge and underestimation of a practical training role;

- inconsistency of the system of qualifications with European standards.

- lack of proper career guidance and appropriate system of vocational selection to the specialization of a teacher of foreign languages;

- low level of psychological and pedagogical culture of students - future primary school teachers;

- underestimation of the importance of scientific, educational, creative and independent activities of students in the professional formation of future elementary school teachers;

- teaching practice being guided by teachers who have not been appropriately trained for work with trainees.

In our opinion, we cannot expect any qualitative staffing of schools with primary school teachers of stable professional and educational orientation until particular steps are made to improve the system of vocational selection of teachers and their professional motivation.

The development of professional primary school teacher training in our country should be aimed at preservation of the undoubted achievements of the national system of teacher education, adoption of the progressive ideas of teacher training practice in other countries, including Hungary, accumulation and synthesis of progressive ideas of the world psycho-pedagogical science and practical experience of building vocational motivation of teachers.

Conclusions. The analysis of characteristics of teacher training in Hungary allowed, firstly, to find out that the training of future teachers is characterized by the integrity, multifunctionality, diversity, practical orientation, flexibility, openness and adaptability to the requirements of the Bologna process; secondly, to outline the ways of further improvement of the national system of teacher training based on the creative use of progressive ideas of the Hungarian experience: formation of professional motivation to educational activities at all levels of education (Bachelor's, Master's, Doctorate programs) in post-graduate education; maximization of professional pedagogical orientation of educational environment in higher education institutions; optimization of preprofessional training; improvement of vocational selection to the teaching profession; harmonization of theoretical and practical components of the professional training; expansion of list of professional psycho-pedagogical and methodical disciplines; greater effectiveness of the curriculum; increase in time allocated for studying psychological and pedagogical sciences; enhancement of teaching practice through the introduction of training of mentors - supervisors of teaching practice; creation of portfolios; wide involvement of students in research work in the field of pedagogy; organization of effective extracurricular educational activities for future teachers.

The performed study does not cover all aspects of the multisided problem of training future teachers in Hungary. The issues of quality of management of training bachelors and masters, the implementation of competence approach in their training require further investigation. 


\section{References:}

Institute of primary school teacher training. Teacher Training Faculty. (n.d.). Retrieved January 15, 2016, from http://www.nyf.hu/pkk/node/132

Az Európai Képesitési Keretrendszerhez való csatlakozásról és az Országos Képesitési Keretrendszer létrehozásáról1 [Creation of the National Qualifications Framework and its accession to the European Qualifications Framework]. (2008). Retrieved January https://www.oktatas.hu/pub_bin/dload/LLL/mkkr/2069_2008_kormanyhatarozat.pdf

Borkach, Ye \&Poor, Z (2010). Realizatsiia pryntsypiv Bolonskoho protsesu u pidhotovtsi vchyteliv v Uhorshchyni [Implementation of the principles of the Bologna process in the training of teachers in Hungary]. Vyshcha osvita Ukrainy, I (19), 401-406.

Levrints, M. (2009). Rozvytok systemy pidhotovky pedahohichnykh kadriv v Uhorshchyni [Development of teacher training system in Hungary]. Naukovyi visnyk Uzhhorodskoho natsionalnoho universytetu. Ser.: Pedahohika. Sotsialna robota, 16-17, 65-66.

Levrints, M. (2010a). Mahisterski prohramy v systemi pedahohichnoi osvity Uhorshchyny [Master's programmes in teacher education system in Hungary]. Naukovyi visnyk Uzhhorodskoho natsionalnoho universytetu. Ser. : Pedahohika. Sotsialna robota, $18,68-72$.

Levrints, M. (2010b). Suchasni modeli profesiinoi pidhotovky vchyteliv v Uhorshchyni [Current models of teacher training in Hungary]. Problemy stanovlennia ta samorealizatsii tvorchoi osobystosti maibutnikh fakhivtsiv humanitarnoho spriamuvannia: zmist, formy ta metody pidhotovky: materialy vseukr. nauk.-prakt.konf. (pp. 71-72). Kharkiv, Ukraine: Kharkivskyi natsionalnyi universytet.

Mis, Y. (2010). Osoblyvosti pidhotovky vchytelia fizyky v Uhorshchyni v konteksti Bolonskoho protsesu [Features of physics teacher training in Hungary in the context of the Bologna Process]. Lichnost'v edinom obrazovatel'nom prostranstve. (pp.86-90). Zaporozh'e, Ukraine.

Nikolaieva, S \& Badaiants H. (2001). Praktykum z metodyky vykladannia inozemnykh mov u serednikh navchalnykh zakladakh (na materiali anhliiskoi movy [Practical course on methods of teaching foreign languages in secondary schools (based on the material of the English language)]. Kyiv, Ukraine: Lenvit.

Ogiienko, O. (2013). Modulno-kompetentnisnyi pidkhid u profesiinii osviti: yevropeiskyi vymir [Module-competency approach in professional education: European dimension]. Profesiina osvita: pedahohika $i$ psykholohiia: Ukraino-Polskyi zhurnal, XV, 179-188.

Ogiienko, O. (2014). Teoretychni zasady innovatsiinoi pedahohichnoi osvity [Theoretical basis of innovative teacher education]. Suchasni informatsiini tekhnolohii ta innovatsiini metodyky navchannia u pidhotovtsi fakhivtsiv: metodolohiia, teoriia, dosvid, problemy,37, 147-151.

Sistemy obrazovanija [Systems of education]. (n.d.). Retrieved January 22, 2016, from http://www.educationsystems.info/item1189.html 